\title{
Coping with religious conflicts
}

Introducing a new concept in conflict research

\author{
Katharina Heyden (iD $\cdot$ Martino Mona
}

Received: 2 September 2020 / Revised: 26 February 2021 / Accepted: 5 March 2021 / Published online: 1 April 2021

(C) The Author(s) 2021

\begin{abstract}
This article presents conceptual results from the Interfaculty Research Cooperation "Religious Conflicts and Coping Strategies" at the University of Bern. Since 2018, researchers from various academic disciplines-theology, psychology, law, religious studies, social anthropology, jewish studies, islamic studies, political sciences, history, communication studies, philosophy, gender studies and german studies-have been comparatively investigating past and present conflicts with religious dimensions.

Conflicts involving religion often intensify, elude resolution or lose their constructive and socializing potential, because strong emotional, factual and interpretive aspects are interwoven. Established strategies of conflict resolution therefore often reach their limits in such conflicts. We show that the concept of coping has the advantage of focusing on the process rather than on the resolution of conflicts. It does not aim at solving a conflict that may not be solved, but it aims at looking for ways to shape and manage conflicts with religious dimensions. Coping as a concept originates from psychologists, who describe individuals as active beings who are able to deal with stressful situations on emotional, factual and interpretative-evaluative levels. The different types of coping correlate with three essential dimensions of religion. Therefore, coping as a travelling concept can be particularly fruitful for the interdisciplinary study of conflicts with religious dimensions. It fosters a context-sensitive and differentiated analysis of the dynamics of religious conflicts and
\end{abstract}

Personal Websites of the Authors Prof. Dr. Katharina Heyden (Theologische Fakultät) https://www.histtheol.unibe.ch/ueber_uns/personen/prof_dr_heyden_katharina/index_ger.html https://orcid.org/0000-0001-5478-1613

Prof. Dr. Martino Mona (Rechtswissenschaftliche Fakultät)

https://www.krim.unibe.ch/ueber_uns/personen/prof_dr_mona_martino/index_ger.html

K. Heyden $(\bowtie) \cdot$ M. Mona

Interfakultäre Forschungskooperation, "Religious Conflicts and Coping Strategies”, Universität Bern, Bern, Switzerland

E-Mail: katharina.heyden@ theol.unibe.ch 
may therefore contribute to develop the approach of conflict transformation. First, this paper presents guiding questions for such a context-sensitive conflict analysis; second, it presents an analytical model that visualizes the relevant conflict factors, dimensions of religion and types of coping and facilitates questions about their interactions.

Keywords Coping · Conflict · Religion · Interdisciplinary conflict research · Travelling concept $\cdot$ Analytical model

\section{Coping mit religiösen Konflikten}

Ein neues Konzept in der Konfliktforschung

Zusammenfassung Dieser Beitrag präsentiert konzeptionelle Ergebnisse der Interfakultären Forschungskooperation „Religious Conflicts and Coping Strategies“ an der Universität Bern. Seit 2018 untersuchen und vergleichen Forschende aus verschiedenen wissenschaftlichen Disziplinen - Theologie, Psychologie, Rechtswissenschaft, Religionswissenschaften, Sozialanthropologie, Jüdische Studien, Islamwissenschaft, Politikwissenschaft, Geschichte, Kommunikationswissenschaft, Philosophie, Genderstudien und Germanistik - Konflikte mit religiösen Dimensionen in Vergangenheit und Gegenwart.

Konflikte verschärfen sich oft, entziehen sich einer Lösung oder verlieren ihr konstruktives und sozialisierendes Potenzial, wenn Religion ins Spiel kommt. Dies liegt daran, dass in solchen Konflikten starke emotionale, faktische und interpretatorische Aspekte miteinander verwoben sind. Etablierte Konfliktlösungsstrategien kommen daher bei Konflikten mit religiösen Dimensionen häufig an ihre Grenzen. Wir zeigen, dass Coping als Konzept den Vorteil hat, nicht auf die Lösung von Konflikten zu fokussieren, sondern auf Dynamiken und Prozesse im Konflikt. Es zielt nicht darauf ab, einen Konflikt zu lösen, der vielleicht nicht lösbar ist, sondern nach Wegen zu suchen, Konflikte mit religiösen Dimensionen zu gestalten und zu bewältigen. In dem ursprünglich aus der Psychologie stammenden Konzept des Coping werden Personen als Akteure angesehen, die in der Lage sind, mit belastenden Situationen auf emotionaler, sachlicher und deutend-evaluativer Ebene umzugehen. Die Coping-Typen korrelieren mit drei wesentlichen Dimensionen von Religion. Daher erweist sich Coping im Sinn eines ,travelling concept” als besonders fruchtbar für die interdisziplinäre Erforschung von Konflikten mit religiösen Dimensionen. Es fördert eine kontextsensible und differenzierte Analyse der Dynamik von Konflikten und kann daher zu einer Weiterentwicklung des Ansatzes der Konflikttransformation beitragen. Für eine solche Konfliktanalyse stellt der Beitrag Leitfragen und ein Analysemodell vor, das die relevanten Konfliktfaktoren, Dimensionen von Religion und Arten des Coping visualisiert und Fragen nach ihren Wechselwirkungen anregt.

Schlüsselwörter Coping · Konflikt · Religion · Interdisziplinäre

Konfliktforschung · Travelling concept · Analytisches Modell 


\section{Religion in conflicts}

Many conflicts, present and past, are perceived and conceptualized as religious. ${ }^{1}$ However, opinions on the role of religion in conflicts are divided-among both scholars and stakeholders. Some consider religion to be a primary cause of conflict. ${ }^{2}$ Others suppose that religions are basically peaceful and are only exploited in conflicts for political or social reasons. ${ }^{3}$ The clash of these opposing views has the potential to complicate conflicts involving religion and to create additional challenges for conflict research and conflict transformation. ${ }^{4}$

But the issue is framed inappropriately when one focuses only on religion as a potential cause of conflict. The question should not be whether or not religion causes conflicts, but when and how exactly religious dimensions become relevant in specific conflicts: Under which political, historical and social conditions does religion cause, fuel, pacify or resolve a conflict situation? How do the varied dimensions of religion interact with other factors in specific conflicts? Do these varied dimensions of religion play a role in distinguishing different types of conflicts, such as a religious identity conflict or a religious issue conflict (Svensson and Nilsson 2018)? And how are they related to successful or failed coping strategies adopted in different conflicts? How do these coping strategies applied by actors involved in a conflict—be they religious or decidedly non-religious - influence the dynamics of a conflict?

In order to answer these questions, it is necessary for various academic disciplines to work together; emic and etic perspectives on religion must complement each other. If academia is to contribute to a better understanding and handling of conflicts with religious dimensions, analytical findings from the social, political and cultural sciences must above all be brought into discussion with more normative concepts from theology, political, social and religious sciences, philosophy and law. This approach is at the heart of the Interfaculty Research Cooperation (IRC) on Religious Conflicts and Coping Strategies at the University of Bern that we established in 2018. In twelve individual interdisciplinary projects, historical and contemporary conflicts with religious dimensions are carefully examined to generate substantive answers to the questions listed above. One major element conjoining these individual research projects is the shared conviction that the concept of coping can shed new light and lead to new and more constructive perspectives on these issues. The common goal is to make the concept of coping, that originates in individual psychology, fruitful for conflict research. This will serve as an important step towards the development of a comprehensive model for the analysis of conflicts.

By introducing coping as a new concept into conflict research, we aim to provide an analytical instrument for further inter- and transdisciplinary investigation.

\footnotetext{
1 A wide variety of definitions and approaches are used to study conflicts with religious dimensions (see Koppe 2010; Crudu and Radu 2011; Frazer and Friedli 2015; Pollack 2018; Krech 2018).

2 The view that religions contain elements that inherently aggravate conflict and promote violence is often held by theologians and historians (e.g., Nirenberg 2013, 2014, 2016; Pratt 2018).

3 This view is often held by social and political scientists (e.g., Bormann et al. 2015; Pelinka 2016).

4 On the ambivalence of religion in conflicts see also Philpott (2007) and Basedau et al. (2016).
} 
It should serve as a context-sensitive and actor-oriented tool for the analysis of the dynamics of conflicts with religious dimensions. Interestingly, the term coping has already crept into research on religions in recent years (Jaspal 2012; Thatcher 2012). In this paper, we will elaborate on this concept, by transferring it to the study of conflicts involving religion (Chap. 2) and addressing the following questions: Is coping as a travelling concept flexible and at the same time precise enough to help us understand the dynamics of conflicts with religious dimensions better (Chap. 3)? What is the advantage of using the concept of coping instead of conflict resolution (Chap. 4)? And to what extent is it more flexible and at the same time more precise than the concept of transformation (Chap. 5)? How should the coping concept be specified and further developed when transferring it from individual to social or political conflicts, so that it proves to be a meaningful analytical tool in conflict research (Chap. 6)?

\section{Coping as a concept in conflict research}

As a scientific concept coping originates in individual psychology and has been developed since the middle of the twentieth century initially in the context of trauma processing with soldiers who had survived the Second World War. Richard Lazarus went beyond defence mechanisms in cases of trauma and an emphasis on pathology to include cognitive and behavioural responses that ordinary people use in their daily lives to cope with negative, particularly stressful situations (Lazarus 1966, 1991).

According to Lazarus, coping thoughts and behaviours are used to regulate distress emotions and to manage the problems causing the distress. In contrast to mere defence mechanisms that distort reality in a rigid and undifferentiated manner, coping is a deliberate process in which humans are no longer described as passive beings exposed to certain processes, but as active beings capable of shaping conflicts.

Overall, coping strategies aim at a re-evaluation of a conflict situation that causes stress (Aldwin 1994); they can focus on different aspects or dimensions of a conflict. As such they also offer a more proactive and self-reliant approach to conflicts compared to the deterministic and more fatalistic approach of psychoanalysis.

Psychological research distinguishes between three coping styles or coping mechanisms (Folkmann and Lazarus 1988; Carver et al. 1989; Zeidner and Endler 1996):

Emotion-focused coping is directed towards one's own feelings. It aims at changing the emotional relationship with a stressful conflict situation (or stressor) that cannot be resolved or changed (Folkman 1997; Pargament 2007).

Problem-oriented coping addresses the cause of stress. It refers to instrumental thoughts and behaviours in order to change the conflictual structures and conditions; it focuses on facts in the outside world.

Meaning-focused or appraisal-focused coping challenges one's own assumptions and aims at alleviating harm or suffering caused by the conflict by cognitive reevaluation and interpretation of a situation. ${ }^{5}$ (Fig. 1).

\footnotetext{
5 The terms meaning-focused and appraisal-focused coping are used synonymously. But since the term meaning-focused is more descriptive, it is better suited for conflict analysis and is therefore preferred here.
} 


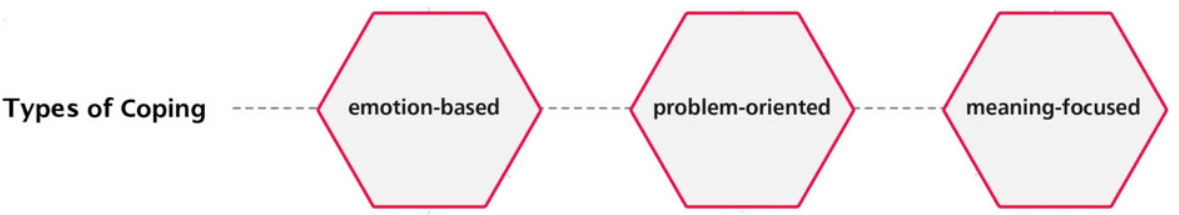

Fig. 1 Types of coping as described in psychology

In everyday life, people use all three types of coping, sometimes overlapping them. In fact, it is usually not possible to determine whether an individual is using just one specific type of coping or a combination of two or even all of them in a concrete conflict situation. Thus, while it is useful to distinguish the three styles in conflict analysis, one should not view them as isolated from one another. Not least due to this tripartite structure, the concept of coping might be attractive for many, especially social and political stakeholders, because it has the potential to provide different coping strategies even for current religious conflicts.

We believe that including the concept of coping will enrich our understanding of and manner of dealing with conflicts in at least three ways:

First, it can help to identify conflicts in a pragmatic way and from the perspective of those directly affected. Whenever we encounter people developing and using coping strategies, we can conclude that there is a conflict. Thus, the mere fact of coping is an indicator of conflict.

Second, distinguishing coping at different levels-emotional, factual, intellectual-allows a holistic approach to conflict that integrates different anthropological aspects and thus opens up new scope for action in conflict situations. This makes coping a helpful concept especially for conflicts with religious dimensions. Practical experience as well as academic research has shown that such conflicts often cannot be solved in a problem-oriented way, because they concern strong value attitudes and convictions.

Third, there are striking parallels between the types of coping observed in psychology and the essential dimensions of religion as described in theological and religious studies. Therefore, the coping concept can help to describe the role of religion in conflicts, and the ambivalent potential of religion to aggravate or pacify conflicts in a differentiated way.

However, to exploit the potential of coping for analyzing and dealing with social conflicts involving religion, the concept must be transferred from the individual level to the social. In other words, coping becomes a travelling concept.

\section{Potential and risk of travelling concepts}

Interdisciplinary collaborative research is faced with a series of challenges: Shared questions, topics and approaches have to be found that enable a discussion across disciplinary boundaries and guarantee the notorious added value. The problem is usually that the various disciplines have developed their own specific concepts, discourses and methods that can only be transferred to other disciplines with great 
loss of precision and diminished standards of reflection. Many academics, especially within humanities, are therefore sceptical about large-scale interdisciplinary clusters and tend to withdraw into their own discipline thereby shutting down potentially illuminating cross-fertilization and exchange of ideas and insights. Some scholars, especially in the cultural sciences, have started to advocate the use of so-called travelling concepts as a promising way out of this dilemma, and they strongly favour travelling concepts as a suitable medium for interdisciplinary research.

The travel metaphor was first introduced into epistemic discourse by Edward Saïd who spoke of "travelling theories" that wander through different disciplines and research fields (Saïd 1983, 2000). The Dutch cultural scientist Mieke Bal then took up the travel metaphor, but preferred to speak of "travelling concepts" instead of theories (Bal 2002). According to Bal, concepts - such as image, framing, performativity, tradition, space and body-are less complex and more flexible than elaborated theories, which can hardly be transferred to other disciplines-indeed, they "wander" into other disciplines and sometimes only leave little trace or get completely reformulated according to the individual needs of the discipline they have entered. Bal states that concepts, on the other hand, "are the tools of intersubjectivity", because they "offer miniature theories, and in that guise, help in the analysis of objects, situations, states and other theories" (Bal 2002, p. 22). This also clarifies to some extent what concepts are not: They are not and shall not be used-or misunderstood - as precise definitions. Concepts do not define their object; they rather "articulate an understanding, convey an interpretation [...] enable a discussion, on the basis of common terms and in the awareness of absences and exclusions" (Bal 2002, p. 23).

The potentials of travelling concepts in research can be summarized as follows:

They foster innovative research by leading researchers to focus on different things than what is familiar to their particular academic discipline. It is also apparent that some travelling concepts, such as transformation, image, intertextuality or performance, have already created new fields of research and study programmes. One reason for this is that they are not bound to a comprehensive theory that is so rich in prerequisites that it cannot be transferred to another academic discipline. Overall, it can be noted that travelling concepts cross borders in four ways: Epistemologically, between the various academic disciplines, culturally, between academics of different cultures and mentalities, diachronically, between historical investigation of the past and empirical analysis of the present and synchronically, between academia and society (Baumbach et al. 2012, p. 6).

At the same time, the risks of using travelling concepts are also obvious: One risk has already been addressed by scholars with a postcolonial approach against Said's travelling theories who pointed out that a concept (or theory) can sometimes be applied to other research fields in a way that endangers the inherent logic of that academic discipline. The Indian historian Dipesh Chakrabarty (2008) called this a "conquest" and a "provincialization" of other fields of research by a ruling theory. In fact, travelling concepts must not be applied in such a way that they attack or replace existing and proven approaches and methodologies of academic disciplines. If this happens, researchers will rightly oppose it. But if one is aware of the danger and tries to avoid such conquest by keeping travelling concepts exceedingly flexible 
and malleable to the notions and understandings already present within the discipline they travel into, another risk arises: The concepts then become vague generalities that can be applied to almost everything. If everything is - in a sense-construction, transformation or image, then these concepts lose their heuristically important function and dissolve into petty metaphors.

Thus, a travelling concept can be a valuable instrument of interdisciplinary research only if it helps to see more or to understand something better compared to the research scenario without that concept. To achieve this, a travelling concept must be both precise and flexible. Travelling concepts therefore have to maintain a twofold balance:

First, it is important that a concept holds the middle position between theory and metaphor. It must be more flexible than a sophisticated theory. And at the same time, it must be precise enough to be able to clearly exclude what does not come into view under the lens of the respective concept.

Second, concepts are not only descriptive, but also programmatic and normative (Bal 2002, p. 28); they categorize and delineate objects of analysis according to specific rules and criteria. In fact, a concept can only be significantly descriptive if it is also normative, i.e., if it sets norms on what the concept encompasses, if it states the requirements.

These are, as a general rule, the conditions for any travelling concept to retain its analytical and heuristic value and thus for finding recognition in different disciplines. This is particularly important when using coping as a travelling concept in conflict research, because it is also a widely used term in ordinary language and thus carries the risk of trivializing a substantive problem as an everyday phenomenon. A purely metaphorical use of the concept of coping in the sense of any kind of reacting to a conflictual situation in some form or another will make the concept somewhat useless, as it lacks the normative force to delimit different objects of analysis into different categories: One must be able to assign instances of human behaviour with regard to religious conflicts into the category of coping or the category of noncoping. Only those instances that distinguish themselves as having fulfilled certain quality requirements should be called coping. Given the background of the coping concept in individual psychology, we would like to apply the following criterion: Coping is always and only present if the intention of stress reduction is explicitly declared as such by the actors or made plausible from the evidence by researchers. Distress, thereby, is not limited to the emotional level, but can also be perceived as a problem at the level of actions and cognition or meaning. Then the question arises: Is the concept of coping flexible and at the same time precise enough to help us understand the dynamics of conflicts with religious dimensions better?

\section{Conflict resolution-conflict transformation-coping with conflicts}

So far, conflict research and conflict mediation have operated mainly within the concepts of conflict resolution and conflict transformation (Schliesser 2019). The shift from conflict resolution to conflict transformation has been significantly influenced by John Paul Lederach $(2003,2014)$. By turning away from the concept of conflict 
resolution and by replacing it with the concept of conflict transformation, Lederach focuses not on solutions, but on the dynamics of conflicts, not on ending conflicts, but on shaping them. He also emphasizes the socializing and constructive effects of conflict, thus trying to free conflict from its purely negative image. Lederach understands conflicts as necessary for the construction of sustainable justice in societies. He states: "Conflict is normal in human relationship and conflict is a motor of change" (Lederach 2014, p. 9). According to Lederach's transformation concept, conflicts are "potential catalysts for growth" (Lederach 2014, p. 16; see also Simmel [1908] 2009 and Werron 2011).

The concept of conflict transformation and the methods Lederach outlined for conflict analysis have been widely received an applied, both in academia and mediation practice. For mediators of conflicts involving religion-be it conflicts between religious groups or conflicts over religious issues-the most promising approach is not to make strong convictions and values the subject of negotiations because those are perceived as not negotiable, but rather to seek pragmatic goals shared by all conflict partners (Bitter 2011; Rasmussen 2011; Frazer 2013; Frazer and Friedli 2015; Ullmann 2018). Recently, however, there has been an increase in voices emphasizing that this approach to transformation also reaches its limits in conflicts with religious dimensions. Conflicts over religious beliefs and strong values cannot only not be resolved, but often also not transformed into non-religious or less religious conflicts (Svensson 2012a, b; Baumann et al. 2018).

On the contrary, conflicts involving religion often intensify and lose their constructive potential because emotional, factual and interpretive levels become blended. To exemplify: While most if not all conflict partners share the view that the child's well-being is paramount, and they even agree to find a pragmatic legal solution to the issue at hand, they still deeply disagree on whether the religious ritual of circumcision is compatible with the child's well-being, some claiming that it clearly violates that principle and some claiming that it is in fact necessary for the overall well-being of the child to undergo this ritual (Fateh-Moghadam 2019). The same can be said for other pressing issues such as a (potential) ban on burqas or mandatory sex education in schools: Most if not all parties involved are eager to find pragmatic solutions and even agree on principles such as equal rights or on the importance of education. Yet, it is clear that even in secular societies there is no getting around the conflicting views on religion and on religious duties in these conflicts. They dominate the respective debates and apparently make it almost impossible to negotiate a truly sustainable solution acceptable to all parties involved. This is where coping as a travelling concept comes into play in several ways:

Like conflict transformation, the concept of coping with conflicts emphasizes the necessary and socializing function of conflicts for the development of freedom and justice in societies. It takes conflict participants not as objects, but as acting subjects who, in their interaction, essentially shape the dynamics of a conflict. It is particularly helpful in view of conflicts with religious dimensions that the three styles or mechanisms of coping distinguished in psychology converge with dimensions of the religious that are relevant in the discussions about defining religion. We are convinced that by integrating factual, emotional and rational-evaluative aspects, the concept of coping fosters a differentiated analysis of the dynamics and development 
of conflicts with religious dimensions within the broader frame of the transformation paradigm. ${ }^{6}$ For now, we would like to simply position the concept of coping in such general and abstract terms and allow the individual projects of our IRC and future similar projects to use this concept as an instrument of their analysis. This shows how, for example, different actors in the debate at hand, be it intra-societal and mostly non-violent conflicts such as circumcision or the ban on burqa, or inter- and intrastate violent conflicts and civil wars, such as radical Islamic terrorism or the Palestine conflict, cope either emotionally, factually or rational-evaluatively.

Thus, by introducing the concept of coping into conflict research, we aim to contribute to further developing and differentiating the approach and the methodology of conflict transformation, with a special focus on conflicts involving religion. This seems particularly useful, since transformation belongs to those travelling concepts that tend to become a mere metaphor, not least because of their inflationary use over the last twenty years. ${ }^{7}$

What is the advantage of using the concept of coping instead of conflict resolution? And to what extent is it more flexible and at the same time more precise than the concept of transformation?

The concept of coping has the advantage of focusing not on a goal, but on the process; not on trying to resolve a conflict that may not be resolvable but on finding ways to handle it. The psychological definition of coping does not imply that the coping efforts have to be successful overall to be considered coping. Coping is what people in fact try to do according to predefined rules when faced with conflict situations in order to reduce harm and stress. This takes place, for instance, when coping is enacted on a societal level by legal regulations: The underlying idea is that the law can be an instrument with which coping can be accomplished; that it can create circumstances in which people are convinced that conflicts have been addressed. In this sense, a central achievement or function of the law lies in objectifying (religious) conflicts by breaking them down into conflicts of specific interests or rights. While not all responses to conflicts can be described as coping, coping efforts might fail but still be called coping.

Within this framework the concept of coping allows for a decidedly actor-centred analysis of conflicts. The understanding of coping as an active handling of conflicts fits very well with the insight into the socializing function of conflicts, as social scientists have emphasized following Georg Simmel ([1908] 2009; Werron 2011; Pelinka 2016). People coping with a conflict are not seen as objects or victims, but

\footnotetext{
6 One might ask whether the most important aspects of coping have not already been addressed by Lederach's concept of transformation-not in words but in substance. Indeed, Joram Tarusarira, Member of the Scientific Board of the IRC Religious Conflicts and Coping Strategies, posed this question at the 2018 Annual Conference at the University of Bern. With the following considerations, we attempt to describe the coping concept not as an alternative to conflict transformation, but as a means of precisely analysing dynamics of conflicts involving religion.

7 Cf. Schliesser (2019) who emphasizes the fluidity of both concepts, conflict resolution and conflict transformation. This fluidity can be seen as an advantage. Within the framework of an epistemic theory of travelling concepts, however, there is a danger that conflict resolution on the one hand is not flexible enough, whereas the transformation paradigm on the other hand runs the risk of not being precise enough and of dissolving into a pure metaphor.
} 
as subjects who actively shape the conflict. Coping is therefore a useful concept for analysing how interacting people, both individual and in group, influence the dynamics of conflicts.

While these aspects can - in substance-be derived from the approach of conflict transformation, coping proves to be more differentiated than the transformation concept in another respect: Coping has already undergone a categorization in individual psychology and is thus already designed and defined precisely enough not to become a mere metaphor as is the case with the transformation paradigm. The established distinction between emotion-based, problem-oriented and meaning-focused coping enables a differentiated and at the same time well-structured analysis of the key elements of conflicts and of the various usually overlapping dimensions of coping with conflicts, which is crucial in conflicts involving religion.

Furthermore, coping is also particularly well suited to the differentiated analysis of conflict transformation because it can relate to all three time levels: Past, present and future. Emotion-based and meaning-focused coping refers to processing of stressful events that lie in the past, while problem-oriented or meaning-focused changing coping intervenes in current conflicts and their evaluation. And all three types of coping (emotion-based, problem-oriented and meaning-focused) can be directed towards the future in the sense of avoiding or managing conflicts.

\section{Coping with religious conflicts}

The differentiation into three coping styles or mechanisms can be related both to the three essential factors in conflicts as described by the political and social sciences (Pelinka 2016) and to three fundamental dimensions of religion, which, despite the complex discussions about a definition of religion, nevertheless mark a consensus in research:

Conflicts often concern actual or felt deficiencies that cause suffering. These can be shortages of raw materials such as water, housing or food, but also immaterial goods such as access to education, social recognition, justice or freedom. The resulting experience of scarcity initially generates emotional reactions, which call for emotion-based coping strategies. Conflicts over material or immaterial goods break out regarding concrete cases and therefore call for problem-oriented coping, which aims at changing the conditions that lead to suffering and stress. Finally, conflicts are marked and shaped by interpretations and discourses, symbols and narratives that form the framework for disputes over the equitable distribution of contingent goods and the validity of convictions and values. These conflict factors as well as the respective coping mechanisms interact and overlap with each other and therefore constitute the dynamics and the complexity of conflicts. (Fig. 2).

As to conflicts involving religion, these often prove to be particularly complex because religion can become relevant not only in relation to one of these conflict factors but can also affect all of them. There is a broad academic debate on whether and how religion can be defined (Werkner 2016; Pollack 2018). Countless attempts at a definition have been discussed so far. However, a certain consensus is emerging on the distinction between different dimensions of religion. For the interdisciplinary 


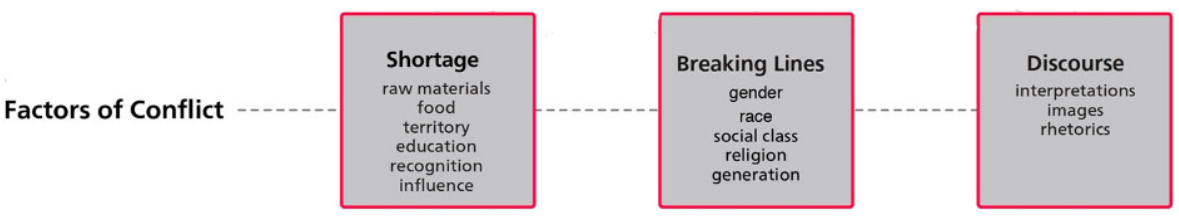

Fig. 2 Factors of conflict as described in political sciences

analysis of conflicts involving religion an approach via various dimensions of the religious proves to be more meaningful than concrete definitions (Krech 2018). The polythetic conceptualization of religion pursued here combines functional and substantial aspects and distinguishes three main dimensions of religion (Kaufmann 1989; Saler 2000; Basedau 2016):

Religion addresses experiences and feelings of contingency (such as death, fate, illness, birth, sublimity, inevitability) and handles the way people feel and act through rituals and lifestyles.

Religion contributes to forming identities at both the individual and group level. In the social sciences, besides generation, social class, gender and ethnicity, religious affiliation is regarded as a breaking line in societies. These are the main categories of belonging and ascription that are used to mark people's identities and along which conflicts are carried out. ${ }^{8}$ Religious belonging, like other social identity markers, has the potential to serve or to hinder the integration in societies through collective obligation. Of particular importance for the understanding of social conflicts is the insight from intersectionality research that conflicts intensify when multiple breaking lines run in parallel. Based on this insight, a strong coping strategy would be to soften and cross such breaking lines (Frazer and Friedli 2015; Ullmann 2018), which can be done on emotional, factual and appraisal focused levels.

Religion influences how people understand the world by providing symbols, narratives, interpretations and teachings with rhetorical means and images. Worldviews and values are not only interpretations that refer secondarily to conflict objects. This is the false premise of those who believe that religion is principally exploited in conflicts and does not have the potential to cause conflicts. The opposite is the case: Religious-or even secular-convictions and values can themselves become roots or triggers of conflicts. (Fig. 3).

Given these dimensions of religion, it is important to understand how they interact and overlap in a specific conflict situation. This can be shown, for instance, by the case of religiously motivated male circumcision. It is a religious ritual which symbolizes the inclusion of baby boys in a specific religious group. As such it is part of a range of religious rituals and structures that are meant to convey identity and affiliation and to give guidance and orientation. It follows that circumcision is not a purely technical intervention that could be postponed until the boy has reached an age where he can decide for himself whether he wants to get circumcised or not.

\footnotetext{
8 While in political sciences, the terms cleavages or conflict lines have been commonly used to refer to such social identity markers (see Pelinka 2016), other disciplines speak rather of "symbolic boundaries" or "categories of ascription" to describe the same phenomenon.
} 


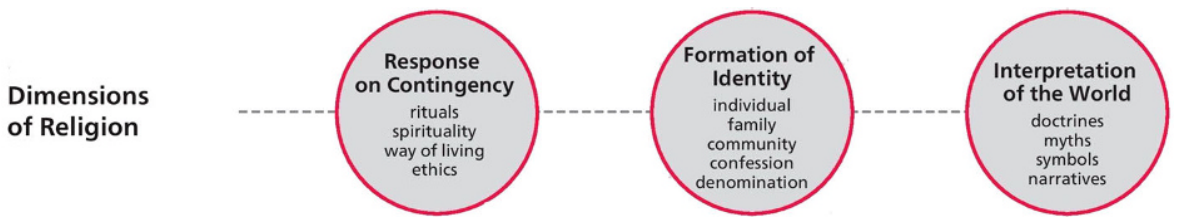

Fig. 3 Dimensions of religion as described in religious sciences and theology

The contrary opinion of opponents of male circumcision might be legally sound and convincing but ignores the crucial ritualized purpose of the circumcision and is therefore seen as presumptuous and even insolent. From the perspective of members of the religion, the legal debate on whether circumcision can be identified as an (illegal) form of bodily harm completely misses the point; it is a ritual that forms identities and provides important narratives, images and values. Due to this strong dichotomy of perspectives and the mutual incomprehension it is unsurprising that the debate quickly turns into accusations of an archaic and barbaric human rights violation from one side and of antisemitism from the other. It shows that religion or religiously motivated behaviour not only can cause conflicts, but also that religion deeply affects how people view and assess certain instances or phenomena and that opposing views are seen as an attack on a certain religion overall.

Finally, different historical and present cases of coping with religious conflicts can be compared and evaluated regarding the different outcomes. Some forms of coping will prove to be more successful in particular conflict situations than others. Thus, the concept also has the potential to advance visions for the development of appropriate coping strategies. It can cross the border between pure descriptive analysis and the more prescriptive recommendation. Given this potential of coping as a travelling concept, we have to pose the question: How must the coping concept be specified and further developed when transferring it from individual to social or political conflicts, so that it proves to be a meaningful analytical tool in conflict research? The following aspects have to be considered:

When coping is transferred from individual to collective processes, several actors with their own coping styles and strategies automatically come into play. These different types of coping have to be analyzed individually, but also in their interaction. Therefore, different degrees of intensity of the intention of stress reduction will also play a role. This also leads to a greater role for problem-oriented and interpretationfocused coping than in individual psychology, where the focus is mostly on emotionbased coping.

The question of how the success or failure of coping strategies can be measured is more difficult to answer in social conflicts than in individual cases. In psychology coping is considered successful when the individual feeling of stress with regard to the balance between person and environment or their requirements and possibilities for action has been reduced; positive forms of coping lead to a better state of health on a personal level. Can this be transferred to groups and societies? And if so, how or by whom can this balance be verified? Is it true that only history can tell? And can history tell us at all? 
When coping is applied to social and political phenomena, power issues become even more important than at the individual level. Power and authority not only play a role on the problem-oriented level, but in sometimes more subtle ways power questions are also of importance on the level of discourse, i.e., meaning-focused coping. Here the question of power arises as a question of sovereignty of interpretation and access to discourses.

In contrast to individual contexts, in social and political conflicts the various forms and acts of coping as well as the success of that coping must be described in a multi-perspective way with regard to many different actors, their intentions and power. A context-sensitive and actor-oriented conflict analysis will be guided by the following questions: Who acts in which way to reduce the stress caused by a conflict for oneself or for others? In which of the three coping categories-emotion-based, problem-oriented or meaning-focused-does the observed behaviour fall or are there mixed forms of coping? And how does this contribute to the dynamics of the conflict? This approach also facilitates the assessment of different coping attempts in view of similar conflicts.

As we have seen with the example of male circumcision, it is impossible to focus on only one dimension without affecting the other. Similarly, it is impossible on a social and political level to adopt a problem-oriented coping approach by, for instance, legally regulating the issue (or by deciding after consideration not to legally regulate the issue) without also deeply affecting the coping taking place on the level of emotions or meaning, such as the importance of certain rituals to strengthen bonds of identity. This in turn can lead to newly felt shortages, e.g., a lack of social recognition or religious tolerance, which again require some form of coping. The question then arises if these negative effects from the political problem-oriented coping on the levels of emotions and meaning can be limited or even avoided if the legal measures adopted are widely accepted as being fair and balanced.

This example shows that the distinction among the three types of coping, developed in psychology, can contribute to a precise analysis of conflict dynamics and thus may provide the precondition for the search for suitable coping strategies. But before we can move on from descriptive conflict analysis to the normative development and assessment of coping strategies for today's conflicts with religious dimensions, a further analytical step must be taken in order to better describe the entanglement of individual and collective aspects of coping with conflicts. Therefore, we propose a further specification in coping styles, coping strategies and coping structures.

\section{Coping styles, coping strategies, coping structures}

Coping in the most general sense means dealing with stressful situations in order to reduce the experience of stress or sadness. To ensure that the term does not diffuse into a mere metaphor meaning simply react to, but remains a meaningful analytical category, the goal of stress reduction must be identifiable whether by conflict actors themselves or researchers from the evidence of data or sources. 
However, one can observe different scopes and intensities of intentionality of coping, and it is worthwhile to distinguish between them when adapting the coping concept to social conflicts. At the most general level, people deal with stressful situations in different ways. They do so individually according to their own experience and feelings; here we refer to coping styles. While coping styles can include some form of self-reflection they can usually be described as being more spontaneous and lacking coordination. Different coping styles can have a great influence on the dynamics of a conflict. Consider, for example, how often spontaneous attempts at coping with wounded religious feelings can influence conflicts.

Coping strategies, in contrast, go beyond styles of coping because strategies presuppose that actors deliberately and intentionally develop procedures and practices and that they reflect on them and on their outcome. Strategic behaviour thus presupposes a certain amount of analysis of the conflict situation at hand including the analytical question on what specific coping category to pick and what the specific goals one wants to reach with a certain coping strategy are. Various specific strategies can be described and classified into the three types of coping. Legal and military solutions, for example, are problem-oriented because they change the conditions of a conflict area. Problem-oriented coping strategies are often accompanied by emotion-based coping strategies like rituals (e.g., flag appeals) or provoke emotion-based coping (e.g., mourning rituals after a terrorist attack). Usually, they are accompanied by meaning-focused interpretations (e.g., whether or not something is God's will).

While coping styles and coping strategies focus on individuals or peer groups that act with a (common) goal, the notion of coping structures takes several types of coping, their intentions, actions and results, into consideration. Coping structures are formed, often over long periods of time, by interacting coping strategies of actors (individuals, groups, institutions) - though only by those communities that have sufficient power and influence to shape society. In their interaction they form social structures - sometimes rather per chance than intentionally - that can be very robust; they can last long beyond the actual coping events and can alleviate or contain future conflicts with similar or different issues. Very robust coping structures can manage to reduce the potential for harmful conflicts over many generations. However, if the social conditions and power relations under which the structures were created change, then the established structures can themselves become the subject of conflict. Since structures are usually not simply created by a few individuals but grow slowly and in often complicated processes through the interaction of coping styles and strategies, only a historical approach to conflicts can help us understand which coping styles and strategies have led to the given structures. To illustrate this, let's take a look at Swiss history.

From the Reformation in the sixteenth century until the nineteenth century the country was affected by religious conflicts, which led to at least five wars (Head 2005; Pfister 2007; Gordon 2002). In the historical sources, various styles of how people coped individually with harm and suffering caused by this conflict can be observed. But also coping strategies applied by various political and religious actors of different social classes can be reconstructed from the sources. Perhaps the most famous is the eating of the Kappeler milk soup. Legend has it that during the first 
War of Kappel in 1529, mercenaries of both conflictual parties, the Reformed city of Zurich and the Catholic villages in central Switzerland, spontaneously cooked and ate a soup of milk and bread together on the front line while the diplomats were still negotiating. Historians doubt whether this meal really took place in the way it is described in the sources. But this act of eating the Kappeler milk soup has become a symbol for the Swiss way of peacefully handling religious conflicts for the benefit of all. Today the Kappeler Milchsuppe is depicted in almost all history schoolbooks, and successful political negotiations are sometimes concluded with the ritual of eating the Kappeler milk soup. ${ }^{9}$ Applying the concept of coping, one could say that this story-be it historically true or be it itself a kind of meaning-focused coping by inventing a symbolic narrative-shows how strategies of problem-oriented coping (diplomatic negotiation) and emotion-based coping (eating together) have led to a very pragmatic solution of a religious conflict.

Historically, the conflict was not sustainably resolved in this way. On the contrary, it took three centuries and at least four more religious wars to establish structures that enabled peaceful coexistence between Catholics and Protestants in the nineteenth century. They are the result of complex and centuries-long processes in which various actors have applied their strategies for handling actual religious conflicts, increasing resilience and avoiding their escalation in the future. Through the ages the event of the Kappeler milk soup has shifted from being the description of a local and partially successful attempt of coping with a pressing religious conflict to being an abstract symbol of a more general strategy and eventually of more robust political and societal structures of coping with similar (religious) conflicts. Underlying this symbol is the statement: We managed to cope with difficult conflicts before, just as they did at Kappel. These structures essentially consist of the following four basic elements: Semi-direct democracy, cantonal sovereignty, i.e., federalism, subsidiarity and the principle of concordance. They are accompanied by the meaning-focused rhetoric of a national (or federal) identity that transcends the confessional boundaries and is the basis of concordance and peaceful coexistence.

However, in the recent past the question increasingly arises whether these structures developed for Christian denominations are still suitable for today, in view of secularization on the one hand and the new diversity and visibility of religion on the other. Majorities have changed; power structures have to be adjusted. Catholic or Protestant affiliation today no longer forms identity to the same extent as in the past (Stolz and Baumann 2009, Stolz 2016). Are the structures robust enough to prevent physical or structural violence and to guarantee peaceful conflict management?

\section{Synthesis and outlook}

A context-sensitive analysis of conflicts with religious dimensions does well to differentiate precisely between the various conflict factors, dimensions of religion

\footnotetext{
9 In 2006, for example, Federal Councillor Pascal Couchepin served a milk soup in public at the end of the so-called St. Gallen Kulturgüterstreit.
} 
and forms of applied coping and to examine their interactions and interconnections. The following model and questions should serve as tools for such analysis. (Fig. 4).

This model does not claim to explain the various conflict factors, dimensions of religion and coping types in their interaction. It merely aims to visualize which aspects can be relevant in conflicts with religious dimensions. Which of those aspects become actually relevant and in what way they interact in a concrete conflict cannot be explained in general terms, but must be carefully analyzed for each individual case. Likewise, styles, strategies and structures of coping should be distinguished and their mutual influence be investigated. In application, it will be important to deal with the model in a dynamic and creative way and to give appropriate weight to the individual aspects. One should imagine the model as a cube that allows one to enter the analysis at a suitable point and to explore the other dimensions from there. For such a differentiated, context-sensitive analysis of religious dimensions in conflicts, the following questions may prove to be helpful.

On the level of coping styles (applied by individuals):

Who acts in which way to reduce what kind of stress? Does the perceived suffering result from a deficiency/shortage-if so, of what kind of shortage?

In which of the three types-emotion-based, problem-oriented, meaning-focused-does the observed coping fall? If mixed forms of coping are present: Which type is primarily addressed? What effects can be observed on the other two levels?

Can specifically religious rituals, lifestyles, laws, beliefs or symbols be identified that either cause the conflict or are part of the observed coping?

How does the observed coping contribute to the dynamics of the conflict? Does it lead to a subjective improvement of the situation? Does it cause stress for others?

On the level of coping strategies (applied by individuals and peer groups):

Which behaviour is used intentionally and in a coordinated manner to reduce stress for individuals or groups in a conflict? Can they be assigned to certain identity markers (social class, gender, race, religion, education)?

Which analysis of the conflict is the basis for the strategies used? Can a deficiency claimed by the actors be identified as the cause of the conflict?

Do the strategies applied aim more at the emotional, action or interpretation level in the conflict? If all levels play a role, can they be described in their relationship?

To what extent does religion play a role in the strategy applied? Are there performed rituals or propagated ways of life? Does the acting group define itself as religious? Are religious narratives, interpretations, symbols or truth claims used in a targeted manner?

Does the strategy address the same level at which the stress is perceived? Or, for example, is a legal situation (problem-oriented) treated in an emotional or meaning-focused way?

Which power structures are used to apply the strategies? Are certain rituals or rhetoric part of the applied strategies? 


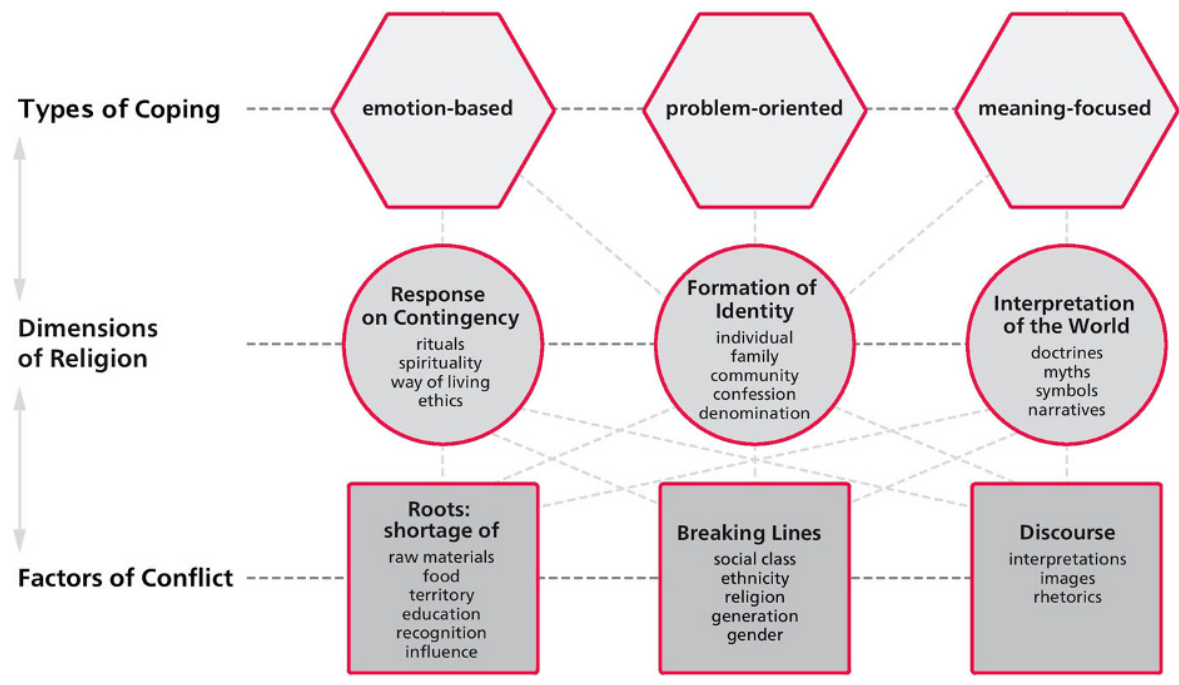

Fig. 4 Analytical model: Conflict factors, dimensions of religion and coping types as developed within the IRC Religious Conflicts and Coping Strategies

How do the applied coping strategies affect the conflict dynamics? Is the strategy successful from the point of view of the actors in the sense that it actually reduces the stress experienced? Does it cause deficiency or stress situations for others in or outside the group?

On the level of structures (established in groups and societies):

What structures have been established for de-escalation of conflicts? Which established structures create a constant potential for conflict?

How do these structures work? Which historically grown power relations manifest themselves in these structures?

Who are the profiteers and who are the disadvantaged in these structures? Can they be assigned to certain identity markers (social class, gender, race, religion, education)?

What role does religion play in these structures? Are certain religious communities de facto (e.g., legally) favoured? Are religious rituals or ways of life used to secure the structures on an emotional level? Are religious narratives or rules cited as justification for the established structures?

Are these structures robust enough to deal with religiously connoted conflicts in a peaceful way? Where do they show potential weaknesses? Under what conditions could this lead to an escalation of the conflict involving religion?

So far, key elements of coping styles-emotion-focused, problem-oriented and meaning-focused-have been introduced as a tool for the differentiated analysis of conflict transformation. We have described them as a prerequisite for the development of coping strategies for today's conflicts. But do the model and the coping concept also have the potential to provide recommendations for current conflicts? 
Can a study of several coping strategies facilitate an answer to the question of what coping strategy can be recommended (or not) for a current conflict situation in order to ensure peaceful conflict-management (including coexistence, cooperation and competition)? These are further questions that need to be discussed in a dialogue between academia and social stakeholders. But we are convinced that a careful analysis of religious dimensions, both the peace-building and the conflict-intensifying, and their interaction with other conflict factors is the indispensable foundation for the development of appropriate coping strategies.

Acknowledgements The article is based on discussions that have taken place since 2018 within an Interfaculty Research Cooperation (IRC) "Religious Conflicts and Coping Strategies" at the University of Bern. In twelve individual interdisciplinary projects, historical and contemporary conflicts with religious dimensions are examined (www.religious-conflicts.unibe.ch). We thank all colleagues from the IRC, and especially the Members of the International Scientific Board: Prof. Anna Sapir-Abulafia (Oxford), Prof. Michael Bongardt (Siegen), Prof. Andreas Feldtkeller (Berlin), Prof. Nicola Lacey (London) and Prof. Joram Tarusarira (Groningen) for valuable impulses which inspired this paper.

Funding Open access funding provided by University of Bern

Open Access This article is licensed under a Creative Commons Attribution 4.0 International License, which permits use, sharing, adaptation, distribution and reproduction in any medium or format, as long as you give appropriate credit to the original author(s) and the source, provide a link to the Creative Commons licence, and indicate if changes were made. The images or other third party material in this article are included in the article's Creative Commons licence, unless indicated otherwise in a credit line to the material. If material is not included in the article's Creative Commons licence and your intended use is not permitted by statutory regulation or exceeds the permitted use, you will need to obtain permission directly from the copyright holder. To view a copy of this licence, visit http://creativecommons.org/licenses/by/4. $0 /$.

\section{References}

Aldwin, Carolyn M. 1994. Stress, coping, and development: an integrative perspective. New York: Guilford.

Bal, Mike. 2002. Travelling concepts in the humanities. A rough guide. Toronto: University of Toronto Press.

Basedau, Matthias. 2016. Ideen, Identitäten und Institutionen: Explikation eines multidimensionalen Religionsbegriffs in der Friedens- und Konfliktforschung. In Religion in der Friedens- und Konfliktforschung, ed. Ines-Jacqueline Werkner, 235-265. Baden-Baden: Nomos.

Basedau, Matthias, Birte Pfeiffer, and Johannes Vüllers. 2016. Bad religion? Religion, collective action, and the onset of armed conflict in developing countries. Journal of Conflict Resolution 60:226-255.

Baumann, Jonas, Daniel Finnbogason, and Isak Svensson. 2018. Rethinking mediation: resolving religious conflicts. In policy perspectives in security policy, vol. 6/1, zurich: center for security studies. https:// www.research-collection.ethz.ch/bitstream/handle/20.500.11850/321562/PP6-1.pdf?sequence=1\& isAllowed=y. Accessed: 19 Mar 2021.

Baumbach, Sibylle, Beatrice Michaelis, and Ansgar Nünning (eds.). 2012. Travelling concepts, metaphors and narratives: literary and cultural studies in an age of interdisciplinary research. Trier: Wissenschaftlicher Verlag Trier.

Bitter, Jean-Nicolas. 2011. Transforming Conflicts with Religious Dimensions: Using the Cultural Linguistic Model. In Religion in Conflict Transformation, Politorbis Zeitschrift zur Aussenpolitik 52, $27-32$. https://www.eda.admin.ch/dam/eda/mehrsprachig/documents/publications/Politorbis/politorbis-52_ EN.pdf. Accessed: 19 Mar 2021.

Bitter, Jean-Nicolas, and Angela Ullmann. 2018. Vom Umgang der Schweiz mit religiösen Konflikten. CSS Analysen zur Sicherheitspolitik 229, 1-4. https://css.ethz.ch/content/dam/ethz/special-interest/ gess/cis/center-for-securities-studies/pdfs/CSSAnalyse229-DE.pdf. Accessed: 19 Mar 2021.

Bormann, Nils-Christian, Manuel Vogt, and Lars-Erik Cederman. 2015. Language, religion, and ethnic civil war. Journal of Conflict Resolution 61:744-771. 
Carver, Charles S., Michael F. Scheier, and Jagdish K. Weintraub. 1989. Assessing coping strategies: a theoretically based approach. Journal of Personality and Social Psychology 56:267-283.

Chakrabarty, Dipesh. 2008. Provincializing Europe: postcolonial thought and historical difference. Princeton: Princeton University Press.

Crudu, Emanuel I., and Laura Radu. 2011. Religion and conflict. In Religion and conflict. Essays on the origins of religious conflicts and resolution approaches, ed. Eric I. Eynikel, Angeliki Ziaka, 231-258. London: Harptree Publishing.

Fateh-Moghadam, Bijan. 2019. Die religiös-weltanschauliche Neutralität des Strafrechts. Zur strafrechtlichen Beobachtung religiöser Pluralität. Tübingen: Mohr Siebeck.

Folkman, Samuel. 1997. Positive psychological states and coping with severe stress. Social Science and Medicine 45(8):1207-1221.

Folkman, Samuel, and Richard S. Lazarus. 1988. Manual for the ways of coping questionnaire: research edition. Palo Alto: Consulting Psychologists Press.

Frazer, Owen. 2013. Mediating conflicts with religious dimensions. In Bulletin zur schweizerischen Sicherheitspolitik 2013, ed. Christian Nünlist, Oliver Thränert, 147-152. Zürich: Center for Security Studies (CSS), ETH.

Frazer, Owen, and Richard Friedli. 2015. Approaching religion in conflict transformation: concepts, cases and practical implications. Zurich: Center for Security Studies (CSS) ETH.

Gordon, Bruce. 2002. The Swiss Reformation. Manchester: Manchester University Press.

Head, Randolph. 2005. Fragmented dominion, fragmented churches. The institutionalization of the Landfrieden in the Thurgau, 1531-1610. Archiv für Reformationsgeschichte 96:117-144.

Jaspal, Rusi. 2012. Coping with Religious and Cultural Homophobia: Emotion and Narratives of Identity Threat among British Muslim Gay Men. In Religion, gender and sexuality in everyday life, ed. Peter Nynäs, Andrew Kam-Tuck Yip, 71-89. Farnham: Ashgate.

Kaufmann, Franz Xaver. 1989. Religion und Modernität: Sozialwissenschaftliche Perspektiven. Tübingen: Mohr.

Koppe, Karlheinz. 2010. Zur Geschichte der Friedens- und Konfliktforschung im 20. Jahrhundert. In Friedens- und Konfliktforschung: Eine Einführung, ed. Peter Imbusch, Ralph Zoll, 17-66. Wiesbaden: Springer.

Krech, Volkhard. 2018. Dimensionen des Religiösen. In Handbuch der Religionssoziologie, ed. Detlef Pollack, Volkhard Krech, Olaf Müller, and Markus Hero, 51-94. Wiesbaden: Springer.

Lazarus, Richard S. 1966. Psychological stress and the coping process. New York: McGraw-Hill.

Lazarus, Richard S. 1991. Emotion and adaptation. New York: Oxford University Press.

Lederach, John Paul. 2003. Conflict transformation. Beyond Intractability. In Conflict information consortium bolder. http://www.beyondintractability.org/essay/transformation.

Lederach, John Paul. 2014. The little book of conflict transformation. New York: Good Books.

Nirenberg, David. 2013. Anti-Judaism: the western tradition. New York: Norton.

Nirenberg, David. 2014. Neighboring faiths: christianity, islam, and judaism in the middle ages and today. Chicago: University of Chicago Press.

Nirenberg, David. 2016. Communities of violence: persecution of minorities in the middle ages. Princeton: Princeton University Press.

Pargament, Kenneth Ira. 2007. The psychology of religion and coping. New York: Guilford.

Pelinka, Anton. 2016. Konfliktforschung. In Friedensforschung, Konfliktforschung, Demokratieforschung, ed. Gertraud Diendorfer, Blanka Bellak, Anton Pelinka, and Werner Wintersteiner, 17-34. Köln Weimar Wien: Böhlau.

Pfister, Ulrich. 2007. Konfessionskonflikte in der frühneuzeitlichen Schweiz: Eine strukturalistische Interpretation. Schweizerische Zeitschrift für Religions- und Kulturgeschichte 101:257-312.

Philpott, Daniel. 2007. Explaining the political ambivalence of religion. American Political Science Review 101(3):505-525.

Pollack, Detlef. 2018. Probleme der Definition von Religion. In Handbuch der Religionssoziologie, ed. Detlef Pollack, Volkhard Krech, Olaf Müller, and Markus Hero, 17-50. Wiesbaden: Springer.

Pratt, Douglas. 2018. Religion and extremism: rejecting diversity. London: Bloomsbury academic.

Rasmussen, Lissi. 2011. Diapraxis: Towards Joint Ownership and Co-citizenship. In Religion in Conflict Transformation Politorbis Zeitschrift zur Aussenpolitik 52., ed. Simon J.A. Mason, Damiano A. Sguaitamatti, 27. https://www.eda.admin.ch/dam/eda/mehrsprachig/documents/publications/ Politorbis/politorbis-52_EN.pdf.

Saler, Benson. 2000. Conceptualizing religion: immanent anthropologists, transcendent natives, and unbounded categories. New York: Berghahn Books.

Saï, Edward. 1983. The world, the text and the critic. Cambridge Mass.: Harvard University Press. 
Saïd, Edward. 2000. Invention, memory and place. Critical Inquiry 26:175-192.

Schliesser, Christine. 2019. Conflict resolution and peacebuilding. In Routledge handbook of religion and political parties, ed. Jeffrey Haynes, 126-138.

Simmel, Georg [1908] 2009. Soziologie. Über die Formen der Vergesellschaftung = Simmel, Georg. Conflict. In Sociology Inquiries into the Construction of Social Forms, Vol. 1, ed. Georg Simmel, 227-305. Leiden: Brill.

Zeidner, Moshe, and Norman S. Endler. 1996. Handbook of coping: theory, research, applications. New York: John Wiley \& Sons.

Stolz, Jörg, and Michelle Baumann. 2009. La nouvelle Suisse religieuse. Risques et chances de sa diversité. Genève: Labor et Fides.

Stolz, Jörg, Judith Könemann, Mallory Schneuwly Purdie, Thomas Englberger, and Michael Krüggeler (eds.). 2016. (Un)believing in Modern Society. Religion, spirituality, and religious-secular competition. London: Routledge.

Svensson, Isak. 2012a. Conflict resolution and religious dimensions of armed conflict. In The Ashgate research companion to religion and conflict resolution, ed. Lee Marsden, 119-135. Farnham: Ashgate.

Svensson, Isak. 2012b. Ending holy wars: religion and conflict resolution in civil wars. Brisbane: University of Queensland Press.

Svensson, Isak, and Desirée Nilsson. 2018. Disputes over the divine: introducing the religion and armed conflict (RELAC) data, 1975 to 2015. Journal of Conflict Resolution 62(5):1127-1148. https://doi. org/10.1177/0022002717737057.

Thatcher, Adrian. 2012. Reading about sex in the bible: coping with ambiguities. In The Ashgate research companion to contemporary religion and sexuality, ed. Stephen J. Hunt, Andrew K.T. Yiop, 79-91. Burlington: Ashgate.

Ullmann, Angela. 2018. Religion und Konflikt in der Schweizer Friedenspolitik. In Bulletin zur Schweizerischen Sicherheitspolitik 2018, ed. Christian Nünlist, Oliver Thränert, 93-116. Zürich: Center for Security Studies (CSS): ETH. https://css.ethz.ch/content/dam/ethz/special-interest/gess/cis/centerfor-securities-studies/pdfs/Bulletin_2018_08_AU.pdf.

Werkner, Ines-Jacqueline (ed.). 2016. Religion in der Friedens- und Konfliktforschung. Interdisziplinäre Zugänge zu einem multidimensionalen Begriff. Zeitschrift für Friedens- und Konfliktforschung. Sonderband, Vol. 1. Baden-Baden: Nomos.

Werron, Tobias. 2011. Zur sozialen Konstruktion moderner Konkurrenzen. In Simmels große „Soziologie‘: Eine kritische Sichtung nach hundert Jahren, ed. Hartmann Tyrell, Otthein Rammstedtra, and Ingo Meyer, 227-258. Bielefeld: transcript. 